\title{
Essays on Nonmarket Strategy
}

\author{
Jin Hyung Kim \\ D.B.A. awarded by Harvard Business School (May 2017)
}

BIG Question:

"In light of the rising importance of nonmarket and political activities of firms, what are the drivers of these political behaviors and how do firms achieve positive economic outcomes through their nonmarket and political strategies in an international setting?"

\section{Introduction}

A Washington Post (2013) article reports that "big companies realized that a few million spent shaping legislation could produce windfall profits," which reflects the fact that many firms see the benefits of nonmarket and political activities. However, it is also true that many company executives often doubt and are uncertain about how they can realize positive outcomes through such activities. The importance of nonmarket activities is not just limited to domestic firms. Foreign firms always face the need to deal with regulatory and institutional environments different from that of their home country when they enter and operate in a foreign market. For instance, the prevalence of current mercantilist view on trade exhibited by some governments is leading up to the trade war and under such circumstance, nonmarket activities of foreign firms in a host country is not fading but gaining more importance. Although many scholarly studies attempt to better understand various types of nonmarket strategies firms use and which of these strategies lead to achieve positive outcomes, our understanding of the topic is far from complete.

Thus, my dissertation, which is a three-essay empirical research, attempts to fill the gap in our knowledge, especially on (1) what drives firms to engage in nonmarket and political activities and (2) what strategies enable firms to achieve positive outcomes through their nonmarket activities. In the first chapter, I carefully examine the relationship between corruption and lobbying behaviors. In the second and third chapter, I show the strategic heterogeneity of firms and how such stra- tegic heterogeneity helps firms to achieve positive economic outcomes.

To conduct this research, I put a lot of effort in building unique datasets; my dissertation intends to overcome the limitations of prior studies by conducting more systematic and reliable analyses by constructing unique datasets. These datasets include (1) US federal lobbying and campaign contribution data, (2) country level institutional, geographic, and economic variables from various sources, and (3) US defense contracts data from the Department of Defense (DoD). In the following sections, I summarize each chapter and discuss the conclusion.

\section{Overview of Essays}

\section{Essay 1 - Do You Lobby Because You Are More Corrupted? No, You Lobby Because It's Legitimate: Evidence from For- eign Firm Lobbying in the US}

The first chapter looks at the relationship between corruption and lobbying. People tend to think that corruption and lobbying are substitutes. This notion is probably driven by a number of recent lobbying scandals and by the negative impression that money can buy politics. In this chapter, Jordan Siegel at University of Michigan and I examine the relationship between corruption and lobbying behaviors of firms using foreign firm lobbying and other political behaviors data in the United States. We find that the degree of corruption is negatively associated with the degree of lobbying.

Corruption as a social norm is deeply ingrained in a society, which affects behaviors of people and organizations embedded in the society. Because of its persistent effect and magnitude, many scholars have paid a lot of attention on corruption. Existing literature on corruption, in general, argues that corruption and lobbying are highly and positively associated, which implies that any form of corruption may substitute any form of lobbying. In other words, corruption and lobbying are seen as 
the same thing, which also aligns with the general perception of lobbying. However, the definition widely accepted and used in the current political science literature is different from how the corruption literature defines lobbying. In principle, current political science literature defines lobbying as an information exchange between political players and interest groups (de Figueiredo and Richter 2014). In more developed countries such as the US, lobbying is a legitimate way of communication, playing a key role in policy making (Hall and Deardorff 2006). As such, lobbying is distinct from corruption, which typically involves illegal or unethical behaviors that are penalized and punished by the law or public if detected (Ades and Di Tella 1999; Shleifer and Vishny 1993).

Thus, in this study, we argue that lobbying is not a substitute for corruption; rather, in more developed economies, lobbying is a legitimate way of communication in policy making. To test this hypothesis, we focused on lobbying behaviors of foreign firms from multiple countries in the US. If lobbying was in fact a substitute for corrupted behaviors, we expected to see countries suffering from high levels of corruption to engage in more lobbying. Empirically, we used a novel US federal lobbying dataset to analyze the relationship between corruption and lobbying at a country level from 1998 to 2012 .

The results confirm our main prediction that there is a positive relationship between lobbying spending and instrumented corruption measures is strongly supported. More specifically, the results show that countries suffering from less corruption (higher instrumented value of corruption index) are more likely to spend more on lobbying. In order to confirm the results, we regressed multiple other lobbying intensity variables such as number of firms lobbied, average number of congressional issues addressed on three instrumented corruption measures. The results still strongly support our prediction that firms from countries suffering less from corruption are more likely to engage in lobbying. In sum, this study shows that one of the most important drivers of lobbying is home country institution, particularly the degree of corruption.

Furthermore, this study provides important implications to policymakers. Contrary to the general notion that corruption and lobbying are substitutes, this study clearly illustrates that lobbying might not be a substitute for corruption but they work in distinct ways. Particularly, strict disclosure of political activities and presence of a strong enforcement and mon- itoring mechanism could make firms' political activities more open and transparent, which could create positive externalities. Thus, this study may be particularly useful for policymakers in countries suffering from corruption who desire to eradicate corruption.

\section{Essay 2 - Let's Talk about the Contract over Coffee and Donuts: Exploring the Bi-Directionality of Agency Embed- dedness in US Government Contracting}

The second chapter, with Shon Hiatt at University of Southern California, focuses attention on one of the mechanisms that could potentially drive positive economic outcomes of nonmarket activities. While most research on business-government relations has focused on firm interactions with political officials, scholars have recently recognized the importance of studying relations between businesses and the administrative state, and the possible ways that firms can influence policy interpretation and execution (Holburn \& Vanden Bergh, 2008). Particularly, from our interviews with multiple defense contractors, we realized that continuous interaction and relationship building with officials in local agencies, which could be as casual as conversations over coffee and donuts, help firms to better understand the needs of these officials. Thus, in the second chapter, we seek to understand agency embeddedness, a mechanism through which firms can influence administrative decisions and obtain positive firm results.

Government agencies heavily rely on outside stakeholders including policymakers for necessary resources and discretion (Carpenter, 2001). A key condition of this support is the agency's effectiveness in implementing policy: the more effective an administrative agency is, the more discretion from legislative oversight and resources it can accrue (Hiatt \& Park, 2013). One important way in which agencies can increase their effectiveness is through agency embeddedness - defined as an agency's "connection with the surrounding social structure" (Evans, 1995: 50). Scholars argue that agency embeddedness positively increases the administrative state's capacity to effectively implement policy and interpret laws by providing government officials with information about the firms they regulate (Evans, 1995).

While most of the research focuses on how embeddedness benefits state agencies, we suggest that the effects of agency embeddedness can be bidirectional and that firms can also be affected by and benefit from their interactions with agency of- 
ficials. Specifically, we argue that firms' geographic proximity to agency decision makers can enhance agency embeddedness by facilitating interpersonal interactions between firms and agency (Tilcsik \& Marquis, 2013). Studies on organizational geography and community have demonstrated that geographic proximity plays a significant role in increasing interpersonal interactions and relationships (Marquis \& Battilana, 2009). Thus, we propose that the closer the distance between firms and government agencies, the greater the agency embeddedness and hence ability of firms to secure favorable administrative outcomes. Empirically, we explored US defense contract awards from 1994 through 2006. Exploring defense contract awards provides an ideal empirical setting to understand the impact of geographic proximity because contracts are awarded by a number of contracting offices at different hierarchical levels of the government and with varying levels of decision-making discretion. Variation in local agency discretion allowed us to examine the boundary conditions of agency embeddedness.

The statistical results confirm that when the distance between the firm and the contracting office is small, firms are more likely to win larger contract amounts, and this effect is moderated by types of contracts made. In sum, this study shows that firms and state agencies influence each other and such interaction can be promoted when there are lower barriers to communicate and build trust. In particular, such strategy is more attractive and effective for domestic firms because foreign firms are not as socially embedded as domestic firms, which attests to the liability of foreignness (Hymer, 1960/1976; Zaheer, 1995). The results also have important implications as regards foreign firms' nonmarket activities in a host country. One of the ways that foreign firms can overcome the liability of foreignness is to possess transferred competitive advantages from the home country, such as knowledge. However, this would be difficult, particularly in cases where industry regulations are high that prevents home country advantages to be transferred. Thus, the results of the second chapter pose an important question about what strategies enable foreign subsidiaries in a host country to overcome such disadvantages. Building on these findings, the last chapter examines the nonmarket strategies of foreign firms that could alleviate the effect of liability of foreignness ultimately to achieve positive economic outcomes.

\section{Essay 3 - Not Sure about Your Capability? No Worries. You Can Buy It: US Defense Contracts and the Lobbying Strat- egies of Foreign MNEs}

Building on the second chapter, the final chapter looks at what strategic heterogeneity allows foreign firms to achieve positive economic outcomes with inherent liability. Literature on political capital unanimously argues that political capital is critical to achieve better nonmarket performance (Siegel, 2007). Assuming that foreign firms are disadvantaged because of their liability of foreignness in a host country (Hymer, 1960/1976;
Zaheer, 1995), it is highly likely that foreign firms might not possess enough political capital they need to execute effective nonmarket strategies. This raises questions about (1) how foreign firms engage in nonmarket activities with inherent disadvantages such as lack of political capital, and (2) whether they achieve their intended nonmarket goals.

Hence, in this paper, I examine these questions by looking at the effect of firm boundary decision in hiring lobbyists on defense contract outcome. I propose that liability of foreignness (Hymer, 1960/1976; Zaheer, 1995) creates heterogeneity in political capital for foreign firms in engaging in nonmarket activities. Due to the characteristics of political capital which can neither be easily transferred from the home country nor built up in the host country comparable to that of domestic firms, I argue that relying on outside political capital manifested as the knowledge/expertise of outside lobbyists and political connections would lead foreign firms to achieve better outcomes. Namely, although foreign firms suffer from liability of foreignness and this penalizes them to sustain the same degree of political capital inside a firm, foreign firms would be able to effectively address their nonmarket interests through outside political capital.

Empirically, I examined US federal defense contract awards from 1998 through 2006, particularly contracts to purchase weapons and related systems. Decisions on weapons purchases are mainly driven by elected politicians and the upper echelon of the DoD, a scenario that makes lobbying an important nonmarket strategy for defense contractors. Moreover, the defense industry is domestically driven and resistant to foreign firms; thus foreign defense contractors have difficulty penetrating the market. This empirical setting is ideal for assessing both the effectiveness of lobbying of foreign-owned defense contractors and its underlying mechanisms. The statistical analyses support that foreign defense contractors gain higher government defense contract amounts when they hire outside lobbyists. Specifically, foreign defense contractors enjoy better outcomes when they hire more experienced lobbyists and lobbying firms with more political connections, complementing their lack of institutional knowledge and less social embeddedness.

To summarize, this study shows that foreign firms can achieve positive outcomes despite suffering from the liability of foreignness. As pointed out earlier, current literature argues that foreign MNEs must possess certain competitive advantages to overcome the liability of foreignness in order to compete against domestic firms (Hymer, 1960/1976; Zaheer, 1995). However, certain industry characteristics make it more difficult for foreign MNEs to gain competitive advantages over domestic firms. The results of this study indicate that in such cases, foreign MNEs might want to supplement their insufficient resources and capabilities by relying on outside firms rather than just relying on their own competitiveness. This finding contributes to an underexplored but important area of internation- 
al business, delineating how foreign firms can achieve positive outcomes through nonmarket strategy.

\section{Conclusion}

Governments not only as rule makers but also as game players increasingly influence the activities of firms by controlling economic and regulatory benefits. Understandably, the role of governments are most salient to foreign firms in a host country. Nevertheless, foreign firms are no longer passive observers but are becoming more active game players in business-government relations. However, our understanding on firms' nonmarket strategies and the outcome of those activities, particularly with regards to foreign firms, is limited at most. Thus, the three essays in my doctoral study take an important step towards better understanding nonmarket behaviors of firms, particularly foreign MNEs in a host country context. Using multiple large-scale datasets and rigorous empirical analyses, I identify institutional drivers of political activities and demonstrate the outcomes of such activities. I am confident that my dissertation study sheds more light on a relatively underexplored area of research where nonmarket strategy and international business intersect. Nevertheless, many questions remain as regards the phenomenon of foreign MNEs' nonmarket activities. Hence, it is my goal to expand our knowledge and to contribute to the international business field by continuing rigorous theoretical and empirical research on this area.

\section{References}

Ades, A., \& Di Tella, R. 1999. Rents, Competition, and Corruption. The American Economic Review, 89(4): 982-993.

Carpenter, D. 2001. The forging of bureaucratic autonomy: Reputations, networks, and policy innovation in executive agencies, 18621928. Princeton, NJ: Princeton University Press.

de Figueiredo, J. M., \& Richter, B. K. 2014. Advancing the Empirical Research on Lobbying. Working paper.

Evans, P. 1995. Embedded Autonomy: States and Industrial Transformation. Princeton, NJ: Princeton University Press.

Hall, R. L., \& Deardorff, A. V. 2006. Lobbying as Legislative Subsidy. American Political Science Review, 100(1): 69-84.

Hiatt, S., \& Park, S. 2013. Lords of the Harvest: Third-party influence and regulatory approval of genetically modified organisms. Academy of Management Journal, 56(4): 923-944.

Holburn, G. L., \& Vanden Bergh, R. G. 2008. Making friends in hostile environments: Political strategy in regulated industries. Academy of Management Review, 33(2): 521-540.

Hymer, S. 1960/1976. The International Operations of National Firms: A Study of Direct Foreign Investment. Cambridge, MA: MIT Press.

Marquis, C. \& Battilana, J. 2009. Acting globally but thinking locally? The enduring influence of local communities on organizations. Research in Organizational Behavior, 29: 283-302.
Shleifer, A., \& Vishny, R. W. 1993. Corruption. The Quarterly Journal of Economics, 108(3): 599-617.

Siegel, J. 2007. Contingent Political Capital and International Alliances: Evidence from South Korea. Administrative Science Quarterly, 52(4): 621-666.

Tilcsik, A., \& Marquis, C. 2013. Punctuated generosity: How Mega-events and natural disasters affect corporate philanthropy in US communities. Administrative Science Quarterly, 58: 111 -148.

Zaheer, S. 1995. Overcoming the Liability of Foreignness, Academy of Management Journal, 38(2): 341-363.

Jin Hyung Kim (jinhyung_kim@gwu.edu) is an Assistant Professor of International Business and joined George Washington University School of Business (GWSB). He received his doctorate at Harvard Business School. His main research agenda is to examine non-market strategy, particularly corporate lobbying strategy and foreign multinational enterprises (MNEs); country and societal institutions and corporate lobbying; and regulatory change and business-government relations. 